\title{
Erosion Control in the Erosion-Ravaged Area of Nanka - Adazi- Nnukwu - Agulu Axis of Anambra State, Nigeria
}

\author{
Onyeka, J.O. ${ }^{1}$, Obi, L.E. ${ }^{1 *}$, Uwanugo, R.G.U. ${ }^{2}$ \\ 1. Civil Engineering Department, Imo State University, Owerri, Nigeria. \\ 2. Civil Engineering Department, Chukwuemeka Odumegwu Ojukwu University, Anambra State, Nigeria: \\ Corresponding author.
}

*Corresponding Author: Obi, L.E., Civil Engineering Department, Imo State University, Owerri, Nigeria.

\begin{abstract}
In this work, we report on an investigation that attempted to address the gully erosion problems of the Nanka - Adazi-nnukwu - Agulu area of Anambra State, Nigeria. With serious erosion leading to deep gullies occurring at unprecedented rates in many parts of Nigeria especially in Anambra State of the country, due partly to the lack of understanding of the erosion processes, and partly to lack of prompt appropriate action by the agencies responsible for its management, the need to properly manage or mitigate its effects has grown. Addressing this problem requires a target-oriented and clearly structured procedure. Simultaneously, it will be necessary to meet relevant legal, engineering, and environmental requirements and to produce designs that are environmental-oriented. The implementation of the erosion-hazard management and the integration of such a management instrument into an existing system, in addition to the use of modern technologies and procedures can help minimize the expanding erosion gullies and solve the erosion problem. The erosion hazard management process proposed consists of three phases: erosion hazard identification, erosion hazard analysis/assessment and erosion hazard handling which are based on each other.
\end{abstract}

\section{INTRODUCTION}

\subsection{Background of Study}

Erosion and excess runoff are products of many factors; the most important are soil types, plant covers, cultivation practices, climatic zones, rainfall amounts and intensities, degree and length of slopes, and conditions brought about by man's activities. Soil erosion is as old as history. Down through the ages, it has influenced the lives of men and destinies of civilization.

Water erosion of land surface is of two types namely sheet erosion and gully erosion. Sheet erosion is the removal of thin sheet of soil in an area while gully erosion is that which forms incised channels. These channels vary in size from small rills that can be back-filled to gullies large enough to seriously threaten the environment.

The end product of erosion is sediment (soil deposit). This can cover roads surfaces, fill road drains, pollute and fill rivers, streams, lakes and dams; damage construction sites and distort the aesthetic disposition of the environment. Not only does the loss of topsoil from agricultural lands or subsoil from highways or road grades result in direct loss from the affected areas, but also it may have a greater economic impact at the place of deposition. Consider the followings;

- The percentage of highways maintenance cost that goes into the removal of sediment from structures, drains, culverts and for filling eroded ditches, slopes, repair of eroded structures and road surfaces.

- Cost of removing the accumulated sediments from homes and industries annually.

- The cost of many areas of fertile river-bottom lands lost annually through the deposition of infertile overwash.

- Streams, rivers, lakes, dams, etc that have their total ecology changed by deposition of sediments or the scouring of new channels.

- The economic loss and the suffering of humans as their homes and economy are destroyed by erosion. 
Erosion Control in the Erosion-Ravaged Area of Nanka - Adazi-Nnukwu - Agulu Axis of Anambra State, Nigeria

- Eroding soil is responsible for much of the water pollution plaguing the world and sometimes, air pollution.

\subsection{Factors Of Erosion}

In addressing ourselves to the problems of soil erosion and its control, we must know the basic fundamentals contributing to it; either as a cause, or agent, or both.

These are principally temperature, wind and water.

A conceptual mathematical model shows the complexity of the problem.

$\begin{array}{lll}\text { Erosion }= & \mathrm{F}(\mathrm{C}, \mathrm{T}, \mathrm{R}, \mathrm{V}, \mathrm{S} \ldots \ldots \ldots \ldots \mathrm{H}) \\ \text { where } \mathrm{C} & = & \text { Climatic variables, temperature, rainfall, wind, humidity, etc. } \\ \mathrm{T} & = & \text { Topography }- \text { slope angle and length } \\ \mathrm{R} & = & \text { Lithologic character }- \text { soil erodibility } \\ \mathrm{S} & = & \text { Soil characteristics } \\ \mathrm{V} & = & \text { Vegetal Cover } \\ \mathrm{H} & = & \text { Anthropogenic factor }- \text { human factor. }\end{array}$

Temperature influences erosion as it disrupts the rock surface through alternate heating and cooling and this weathering process prepares the material for transportation by wind and water. Wind erosion is a problem found principally in the more arid, sparsely vegetated regions. It is also of local importance along the edges of highways pavements or earth roads where the turbulence of passing traffic removes significant quantities of unprotected soil. Water erosion is one of the most common geological phenomena. It accounts in large part for the leveling of our mountains, and the development of plains, plateaux, valleys, river flats and deltas. This is normal erosion and it operates slowly. When erosion exceeds this normal natural rate, as a result of erosion factors, and becomes unusually destructive, it is said to be accelerated.

\subsubsection{Geomorphology}

The topography features prominent in the study area are uplands, lowlands, stream channels, and gullies of variable dimensions scattered in Agulu/Adazi-nnukwu/Nanka geographical area. It is convenient to separate the topography of Agulu/Adazi-nnukwu/Nanka area into two contrasting landforms; namely the western upland (Nanka sands terrain) and the eastern lowland (Imo shales environment) Ajaero and Mozie (2019). These landforms vary in elevation from $65 \mathrm{~m}$ to $212 \mathrm{~m}$ above sea level. The gully complex of Nanka - Oko and the Odo-Ubamili valley systems features on the east-facing scarp slope of the cuesta.

\subsubsection{Geology}

The Agulu lake is situated at latitude $5^{0} 15^{\prime}-5^{0} 55^{\prime}$ and longitude $7^{0}$

$15^{\prime}-6^{0} 55^{\prime}$ in the Anambra basin. According to Egboka (1994), the basin was produced by the subsistence of the Anambra plate due to folding and uplift of the Abakaliki - Benue plate in the santonian stage. The basin is filled with elastic sediments constituting several distinct lithostratigraphic units deposited from upper Campania to recent. The litostratigraphic units have thicknesses of up to $2,500 \mathrm{~m}$. These include: Nkporo shale, Nanka/Ameki sands/formation, Nsugbe formation and Ogwashi - Asaba formation. The sediments were derived from the uplands beyond the Benue High Line, the Abakaliki uplands and the Benue fold belt.

According to Egboka (1985), the dominant geological formation at Agulu - Nanka area is the Eocene Nanka sands. It is a sequence of unconsolidated or poorly consolidated sand, $305 \mathrm{~m}$ thick, underlain by the lignite - clay seams of the Ogwashi - Asaba formation. Akpokodje, Olorunfemi and Etu-Efeotor (1986) described the Nanka Sand (Eocene) as a member of the Ameki formation. Rocks of this formation range from fine-medium-coarse sands (which are littered with gravels and pebbles of variable sizes) to shale to clay to siltstone to subsidiary lignite, etc. Its heterogeneous character is clear indication of stratification under shallow marine to continental environments. This sand unit 
Erosion Control in the Erosion-Ravaged Area of Nanka - Adazi-Nnukwu - Agulu Axis of Anambra State, Nigeria

constitutes the upper horizon of the Ameki formation. It underlines a strip of country stretching northwest-southeast of the map area. (See appendix1).

Nanka sand is strongly dissected in places by perennial and seasonal running waters. This dissection is in consonance with the active gullies ravaging parts of the vulnerable Nanka Sand district, thereby, giving rise to a negative relief feature of variable magnitudes. The sand member is characteristically friable, moderately to poorly to fairly well (at lower horizon) sorted, white with variegated shades of yellow, pink, purple and purplish red. According to Nwajide and Hoque (1979), a total thickness of about 320m has been established around the Agulu - Nanka complex area. Occasional lenses of ferrugunized and industrated sand stone (iron pan) are apparent at the upper and lower levels and graded current bedding is occasionally a feature of sand stone unit. Bands of light coloured (sometimes purplish/reddish) clays varying in thickness from $0.3 \mathrm{~m}$ to $3 \mathrm{~m}$ and above occur in the upper horizons. The middle zone is ramified with numerous streaks of clay evenly and closely spaced, whereas the lower portion of the Nanka sand sequence is interbedded with dark shale containing specks of mica, gypsum and granular pyrite. According to Egboka (1994), these sand units, separated at shale-slit-fine sand layers could be as thick as $30 \mathrm{~m}$ in some places. The deposits also exhibit well developed patterns of alternating cross-bedded sands and layers of dark gray shales. The shale units generally occur in the beds $40-50 \mathrm{~cm}$ thick; alternating with fine sand and siltstone. The component beds and laminae exhibit a wide variety of colours often arranged in bands. The units generally have a low angle of dip ranging between $7^{0} \mathrm{E}$ and $9^{0} \mathrm{~W}$.

The Imo formation comformably underlines the Ameki formation. Ajaero and Mozie (2019) observed that the Imo formation (shallow marine sediments) is older than the Ameki formation (mostly continental sediments) and are both of tertiary age. According to him, the Imo formation is comprised mostly of argillaceous rocks. It is made up of dark gray shales, sandstone, lime stone, silt stone and calcareous mudstone with abundant shells of gastropods and branchiopods occasionally well preserved in the sediments. The Imo formation of the study area is predominantly shale (Ajaero and Mozie, 2019).

\section{METHODOLOGY}

The method employed in this research is a sustainable and clearly structured procedure. It also employed relevant engineering and environmental requirements to produce designs that are sustainability-oriented. The interface between a base soil and drainage channel or masonry embankment is very prone to wash-out (erosion); especially in fairly steep cohensionless soils. This Musgrave's empirical relationship (equation)

$$
\mathrm{E}=\mathrm{CR} \cdot\left(\mathrm{S}_{0} / 10\right)^{1.35}(\mathrm{~L} / 72)^{0.35}\left(\mathrm{P}_{30} / 1.25\right)^{1.75}
$$

exits between soil segregation and rainfall intensity, erodibility of soil, length and steepness of slope and vegetal cover.

where $\mathrm{E} \quad=\quad$ Erosion of soil lost from a catchment in centimeter/year.

$\mathrm{C}=\quad$ Soil erosion rate, which varies from 0.43 to 0.53

centimeter/year depending on the soil type (which depends on texture and permeability of soil).

$\mathrm{R}=\quad$ The soil cover factor, which varies from 0.95 for poorly covered land to 0.10 for row crops.

$\mathrm{S}_{0} \quad=\quad$ Land slope in percentage, the default being $10 \%$.

$\mathrm{L}=\quad$ length of the land slope in centimeters.

$\mathrm{P}_{30}=\quad$ The max. Rainfall in centimeter having 30 minutes duration and of 2 year frequency. (Morgan, 1978) reported of Musgrave suggesting this equation.

Although originally developed for agricultural use, the equation has been modified for constructional uses by the introduction of erodibility factors for subsoils and used to predict soil losses from a given site. Such predictions may influence the design of an infrastructure or the treatment required for soil stabilization. 
Erosion Control in the Erosion-Ravaged Area of Nanka - Adazi-Nnukwu - Agulu Axis of Anambra State, Nigeria

\section{Sustainable Soil ERosion CONTROL Measures}

\subsection{Soil Conservation Design}

Considerations pertinent to soil conservation design are:

- The area (flood basin) that contributes to sediment loads flows (overland flows or runoff) should feature in competent sheet flow velocity with regard to their top soils.

- The factors that enhance top soil segregation should be reduced.

- Seepage of water through soils resulting in enhanced slope failure.

The above two requirements are considered below

\subsubsection{Reduction in Soil Migration in Sheet Flows}

The composite overland flow velocities should be estimated for each catchment area as the length of overland flow divided by the time of concentration. The soil transportation competence of these velocities can be deduced from a table of competence of streams as shown on Table 1 .

Table1. Competence of Stream

\begin{tabular}{|c|c|c|c|c|}
\hline Materials & $\begin{array}{c}\text { Average Velocity } \\
\text { Current (m/sec.) }\end{array}$ & $\begin{array}{c}\text { Threshold Ground Slope on } \\
\text { Different Flow Lengths L=0.5km }\end{array}$ & L=1.0km & $\begin{array}{c}\text { Comparative } \\
\text { Erosion }\end{array}$ \\
\hline Fine Sand & 0.2 & $5.37 \times 10^{-7}$ & $3.91 \times 10^{-7}$ & Low \\
\hline Medium Sand & 0.3 & $121 \times 10^{-6}$ & $8.79 \times 10^{-7}$ & Low \\
\hline Coarse Sand & 0.4 & $215 \times 10^{-6}$ & $1.56 \times 10^{-6}$ & Medium \\
\hline Granite Sand & 0.6 & $4.85 \times 10^{-6}$ & $3.52 \times 10^{-6}$ & Medium \\
\hline Pebble Sand & 1.6 & $3.44 \times 10^{-5}$ & $2.50 \times 10^{-5}$ & High \\
\hline Boulder & 11.7 & $1.83 \times 10^{-3}$ & $1.33 \times 10^{-3}$ & Super high \\
\hline
\end{tabular}

A comparative susceptibility of an erosion prone catchment area or a catchment area erosion competence pattern based on the above deduction can be evolved under a hydrologic design as an indicator of the following soil conservation design factors:

- The soil material susceptible to erosion at the present state of the catchment areas.

- The comparative severity of erosion hazard at the present state of the catchment areas.

The threshold ground slopes for various streams - competent velocities are also presented in table 1 . Each has been obtained from a modification of time of concentration (TOC) equation, thus

$\mathrm{S} \quad=\quad 0.0000097 \mathrm{~V}^{2} / L^{0.46}$

$\mathrm{S}=$ ground slope

$\mathrm{V}=$ mean channel flow velocity $(\mathrm{m} / \mathrm{sec}$.)

$\mathrm{L}=$ length of channel flow.

It is seen from table 2.1 that the threshold ground slope for the erosion of the same soil particles varies for different flow lengths (L) and that the variation is inverse with $L^{0.46}$. This demonstrates the importance of reduction of slope length in erosion control. Although, outside the land use area, the flow beds of canyons, gorges and gullies feature as the major routes of soil sediment migration in the general sediment balance during erosion. This is primarily due to their expansive storm run-off catchment areas generating swift flows over their unvegetated surface without any velocity reducing features. It is also due to the sediment contribution from the active section of their embankment in mass erosion. The flow beds undergo seasonal changes of grade through erosion incision and sedimentation between the advent and recession of the rains. The bed incision accelerates the above sediment transportation role and enhances the growth of more active canyons, gorges, or gully sections. Some measures for the control of the above incisions at the canyons, gorges, and gullies beds are illustrated below.

\subsubsection{Flow Velocity Control}

Of prime value in any erosion control scheme is the control of flow velocity of surface run-off. Fig. 1 illustrates this point as shown; 
Erosion Control in the Erosion-Ravaged Area of Nanka - Adazi-Nnukwu - Agulu Axis of Anambra State, Nigeria
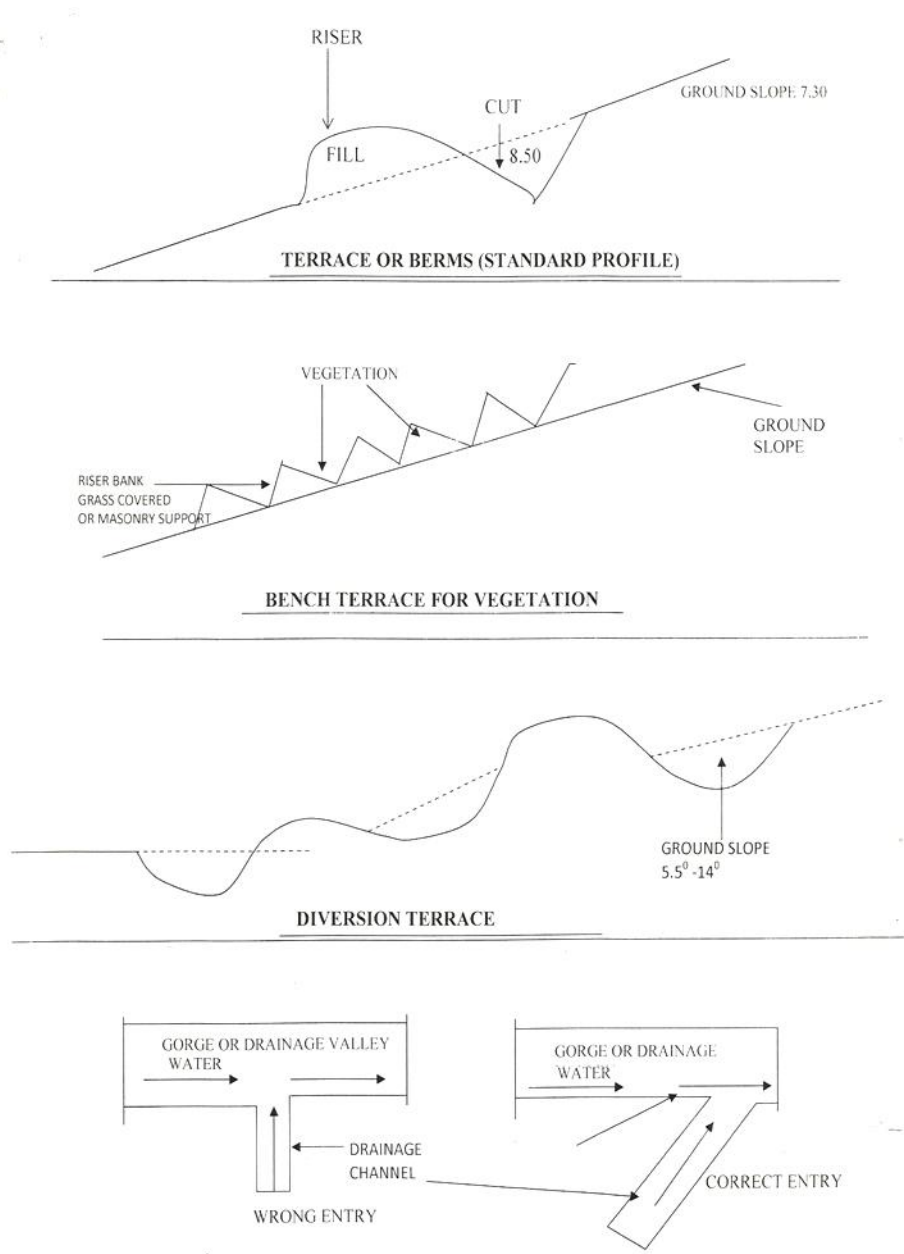

Fig1. Arrangement of erosion control structures.

For example, at a velocity of between $30 \mathrm{~cm} / \mathrm{sec}$ and $60 \mathrm{~cm} / \mathrm{sec}$, a particle of $0.02 \mathrm{~mm}$ size would be loosened from its bed. Beyond $60 \mathrm{~cm} / \mathrm{sec}$, the particle would be in suspension. Once in suspension, the particle is capable of being transported at a velocity even as low as $0.15 \mathrm{~cm} / \mathrm{sec}$. At a lower velocity of $0.15 \mathrm{~cm} / \mathrm{sec}$, sedimentation would take place. Table 2 shown below illustrates the range of velocities needed to ensure stability of unlined channels which ranges from $0.5 \mathrm{~m} / \mathrm{sec}$ for unlined channels in sand to $2 \mathrm{~m} / \mathrm{sec}$ for unlined channels in cobbles and shingles. Flow velocities should also be limited to avoid erosion (scouring) of channels walls as illustrated in Table 2.

Table2. Permissible Velocities for Channels with Erodible Linings

\begin{tabular}{|c|c|c|c|}
\hline \multirow{2}{*}{ Soil Type } & \multicolumn{2}{|c|}{ Minimum Permissive Velocities } \\
\cline { 2 - 4 } & Clear Water & Water Carrying Fine Silts & $\begin{array}{c}\text { Water Carrying Sand and } \\
\text { Gravel }\end{array}$ \\
\cline { 2 - 4 } & M.S & M.S. & M.S. \\
\hline Fine Sand & 0.46 & 0.76 & 0.46 \\
\hline Sandy Loam & 0.52 & 0.76 & 0.11 \\
\hline Silt Loam & 0.61 & 0.91 & 0.61 \\
\hline Ordinary Firm Loam & 0.76 & 1.07 & 1.13 \\
\hline Fine Gravel & 6.76 & 1.52 & 0.91 \\
\hline Stiff Clay & 1.13 & 1.52 & 1.52 \\
\hline Graded, Loam to Cobbles & 1.13 & 1.52 & 0.52 \\
\hline Graded, silt to Cobbles & 1.22 & 1.07 & 1.07 \\
\hline Alluvia silts (Non-colloidal) & 0.61 & 1.07 & 1.98 \\
\hline Alluvia silts (colloidal) & 1.13 & 1.52 & 1.98 \\
\hline Coarse Gravel & 1.22 & 1.83 & 1.52 \\
\hline Cobbles and shingles & 1.52 & 1.68 & \\
\hline Shales and Hard pans & 1.83 & 1.83 & \\
\hline
\end{tabular}

Source: Highway Manual Part 1, Design (FMW\&H), 1993. 
Erosion Control in the Erosion-Ravaged Area of Nanka - Adazi-Nnukwu - Agulu Axis of Anambra State, Nigeria

\subsubsection{Reduction of Soil Segregation}

\section{Rainfall Erosivity.}

The empirical relationship between soil segregation and rainfall intensity is still undergoing research. Three such relationships have been presented by Morgan who also reported about $69 \mathrm{Jm}$ storm at Ibadan. Two of such reliable relationships are stated thus:

a. Wischmeir-Smith formula

$\mathrm{KE}\left(\mathrm{Jm}^{-2} \mathrm{~mm}^{-1}\right)=11.87+8.73 \log 1$

b. Zachi Torri formula

K.E. $\left(\mathrm{Jm}^{-2} \mathrm{~mm}^{-1}\right)=9.81+11.25 \log 1$

K.E. $=$ Kinetic Energy in $\mathrm{Jm}^{-2} \mathrm{~mm}^{-1}$

I $\quad=\quad$ Rainfall intensity in $\mathrm{mm}$.

The above kinetic energy generates soil erosion first by soil segregation, then by soil transportation either by outright carriage in overland sheet or rill flows, soil splash or both. Values of kinetic energy using available data for heaviest rainfall values for Nanka/Adazi-nnukwu/Agulu catchment area are presented by Nwajide and Hoque.

The sub-basin areas involved here are cultivated lands whose crops do not produce early foliage cover before rains, bare areas on construction sites and bare soils under roof-lines within built-up areas.

\subsection{Soil Conservation Measures}

The major soil migration in sheet flow have been identified earlier and summarized as:

a. The bare slopes with scour-competent over-land flow velocities.

b. Earth roads/unlined drains with scour-competent over-land flow velocities

c. Flows-beds of canyons, gorges and gullies.

d. Base soils on construction sites under roof lines in built-up and cultivated areas.

The soil conservation measures include:

1. Grassing/tree planting i.e. Agro forestry.

2. Construction of sedimentation weirs, etc.

3. Construction of wooden groynes.

4. Construction of retaining walls and revetments etc.

\subsection{Human Activities that Propagate Soil Erosion}

Since the first ancient crude plow uprooted the first square meter of soil and since man's axe first hit virgin forest, soil erosion had been a problem.

\subsubsection{Deforestation/Poor Cultivation Practices}

Plants such as trees, shrubs and grasses that cover the land reduces rain drop size, intensity and velocity. It reduces soil particle transportation by hindering high runoff velocity. In erosion prone areas, proper farming methods, proper construction and land preparation practices should be encouraged, e.g., farm ridges should be constructed across slopes not along slopes. Land terracing should be employed. The vertical ridges (drops and rises) acting as mini-water falls in breaking the momentum of water while the horizontal stretches (treads) act as tiny dams storing water.

\subsubsection{Construction Pattern}

Roadways and other constructions annually reshape thousands of hectares of land in the country (Nigeria). High rates of soil loss and resulting sediment yields from construction sites cause serious erosion problems. Even where plans are included for run-off control such as re-vegetation, a lot of problems are caused during construction. 
Erosion Control in the Erosion-Ravaged Area of Nanka - Adazi-Nnukwu - Agulu Axis of Anambra State, Nigeria

\subsubsection{Quarrying and Borrow Pit Mining}

Quarrying for sand and hardcore materials with its attendant deforestation and alteration in the existing land terrain obviously leads to soil erosion.

Quarrying must be discouraged in erosion prone areas, in undulating terrains and along the sides of our highways. Where quarrying is done, revegetation must follow while run-off must not be allowed to flow unguided.

\subsubsection{Proper Outlet of Drains at Drain Outfalls}

One of the most common factors in man-made causes of gully erosion is the improper or poor termination or non-provision of adequate outlet structure at the end of drains. The concentration of run-off through a culvert or drain outlet into a lower ground basin (moat, valley, river, active or inactive gorge, etc.) constitutes a waterfall, hence creates a gully-head. This gully-head recedes and increases, swallowing up the drainage channel.To check this, construction of adequate outlet structure to dissipate the run-off kinetic energy (e.g. through splaying, placing of obstacles, etc. before flowing into the discharge medium that discharges into unlined outlet should be at an angle less than $30^{\circ}$ ) and never at right angles.

\subsection{Application of Agro-Forestry in Controlling Erosion in the Study Area}

\subsubsection{The Use of Herbaceous Plants for Erosion Control}

In conjunction with the use of structures for the control of soil erosion, the use of good vegetative cover must also be emphasized. The nature and extent of vegetative cover to be provided should be dependent on the closeness of the forest canopy. The vegetation canopy coupled with any herbaceous ground cover and forest litter dissipate the kinetic energy of rain drops. The litter ameliorates the soil structure, impedes water movement, and acts as a filter through which water enters the soil slowly devoid of any suspended particle which could clog pores. The surface soil thus assumes an open structure through which water infiltrates rapidly and the movement of the water down the profile is facilitated by cracks and channels created by living and dead roots.

There is tendency for people to regard afforestation as synonymous with tree planting alone. The mere planting of any type of plant on bare soil without regard to the ecological principles may not give the required result.

For afforestation to serve as an effective control measure, a good understanding of the nature and functions of the ecosystem in question, and of the development and structure of the vegetation is required. This understanding will guide one in choosing the plant species that would be effective for the purpose. Any afforestation programme short of mimicking nature is bound to be ineffective.

An integrated approach to erosion control in the study area is recommended. Among the specific characteristics that must be considered in selecting plans for use as vegetative cover include crop growth habits, root depths, tolerance to adverse conditions, seed properties, i.e., propagation trends, aesthetic qualities, required maintenance, and possible crops harvestation.

\subsubsection{Ground Cover Establishment}

The use of ground cover as the first step towards afforestation in the research area is recommended. The plants that constitute the ground cover are the most important members of the vegetation that play important roles in the prevention and control of erosion. The recommended ground cover plants are vetiver nigritana and paspalum notatum. The ground cover plants are invaders of exposed soils. They are well adapted to the environment, including the extremes of temperature, moisture and nutrient status. They produce numerous roots which spread and form a mesh ranging from a few centimeters below the soil surface, as in paspalum notatum, or go deep into the soil as in vertiver nigritana which has roots that are up to 3 meters long. Paspalum notatum has a creeping habit, high tolerance of temperature extremes and low nutrient status. This confers on it the ability to establish and cover the ground in a short period of time if the area is undisturbed. Its numerous roots which spread below the soil surface bind the soil particles together. This action of binding the soil particles together with their roots and increasing the organic contents of the soil make the environment conducive for woody plants to establish. 
Erosion Control in the Erosion-Ravaged Area of Nanka - Adazi-Nnukwu - Agulu Axis of Anambra State, Nigeria

\subsubsection{Woody Plants (Trees And Shrubs)}

These are importance in erosion control. They play the role of nutrients recycling because they serve as nutrients pumps, bringing to the surface nutrients leached to the deeper horizons in the form of leaf litter and other residues. The leaf litter and other residues modify the soil porosity and infiltration rates leading to reduce erodibility of soil and improving the efficiency of nutrients recycling within the plant system.

Afforestation for erosion control purposes requires that the plant species should have the following characteristics:

- Fast rate of growth

- Low nutrients requirement, with wide site tolerance range

- Nitrogen fixing ability to conserve the use of chemical fertilizers

- High fertility-restoration ability through high organic matter production

- Good rate of litter decomposition

- Deep rooting system

- Drought resistance

- Ability to regenerate through cropping

- Easy and cheap management

- Provision of some economic products

Based on the above requirements, the following trees and shrubs are recommended for the agroforestry intervention and erosion control in the research area as shown on Table 3

\begin{tabular}{|c|c|c|}
\hline & PLANTS & ECONOMIC VALUES \\
\hline 1. & Dacryodes edulis & - Edible fruits \\
\hline 2. & Irvingia gabonensis & - Edible nuts \\
\hline 3. & Treculia Africana & - Edible nuts \& fodder \\
\hline 4. & Pentacheltramacrophlylla & - Edible nuts \& fuel \\
\hline 5. & Garcinia cola & - Edible fruits \\
\hline 6. & Mangifera indica & - Edible fruits \& nuts \\
\hline 7. & Anarcadium osidentails & - Poles for scaffolding and fodder \\
\hline 8. & Gmelina arborea & - Fodder \\
\hline 9. & Ricinodendron heudeloti & - Fuel wood, fodder, poultry feed, fertilizer \\
\hline 10. & Leuceana leucocephala & - Edible leaves \\
\hline 11. & Pterocarput spp & \\
\hline
\end{tabular}

\subsubsection{Vetiver Nigritana}

The vetiver grass is most effective when used to form contour edges against a slope. It has the following characteristics which make it ideal for soil conservation and gully stabilization.

a. It has a deep, strong fibrous root system (3m deep)

b. Planted at the correct distance (20 cm apart), it will quietly form a dense hedge underlined by a dense curtain of roots binding the soil along the contour

c. Once established, it is generally unpalatable to livestock

d. It is perennial and will last as a hedge, not requiring maintenance for years

e. It can withstand fires, drought, inundation and floods

f. Its leaves and roots have demonstrated a resistance to most pests and diseases, making the leaves useful mulch for fruit trees planted in rainfall areas.

\subsubsection{Tree Planting Techniques to Be Adopted for Effective Control of Erosion in the Research Area.}

Attempting to grow trees on eroded slopes result in very poor uneven stands not worth the cost of maintenance and not well established to protect the soil against erosion and provide other by-products. This is because moisture distribution cannot be controlled. This problem can, however, be overcome 
in the research area of Nanka/Adazi-nnukwu/Agulu using the alley cropping approach. This is a system whereby plants are used in forming contour hedges against the slope while using the spaces inbetween the hedges for cropping or planting of multi-purpose trees or forest trees. Vetiver Nigritana and Leuceana Leucocephala_are recommended for use as the hedge plants.

The following is a recommended method of establishing tree crops on eroded slopes:

- Contours should be pegged out on the slopes

- Shallow V-ditches should be dug along the contours either by hand or by bulldozer

- Vetiver grass or Leuceana Leucocephala should be planted in the V-ditches

- The multi-purpose trees should be planted near the end of the V-ditches.

Under this system of planting, water, nutrients, organic matter and mycorrhiza are all harvested from the slopes and collected in the trenches for the benefit of trees, and the entire system is stabilized by the Leuceana or Vetiver hedge. Because of this water-harvesting effect, the trees can be planted closer together in the intra-row and a little further apart in the inter-row. This also ensures a more effective protection of the soil by the trees.

This system of contour V-ditches enables trees to be planted without the need for irrigation in the first three years of establishment. The collection of water in these contour trenches has the effect of doubling or tripling the amount of annual rainfall. The run-off from the inter-rows between the trees is held in the trench and ultimately behind the Vetiver hedge, and it has time to soak right into the soil at the base of the trees. Once the dry season sets in, Vetiver grass can be cut to ground level and its leaves used as mulch at the base of the fruit trees to help retain moisture.

Leuceana Leucocephala has the added advantage of enriching the soil through its ability to fix nitrogen (as it is a legume).

The loppings of Leuceana can also be used for fodder and fuel woods.

Prunnings of Leuceana leucocephala can also be used for mulching to prevent sheet erosion between trees. On even ground, trees can be planted in well-matured ditches of about $60 \mathrm{~cm}$ deep and wide; and with inter and intra-row spacing of 10 meters. The manure application is due to the low nutrient level of soil in the area, and it is to boost the growth of the trees in the first year of planting.

\subsection{Erosion Control Structures that Could be used in Contolling Erosion in the Research Area}

There are a wide variety of engineering structures that can be used in check-mating surface run-off. It must be emphasized that to be effective and economical, erosion control structures must be designed into a project and not added cosmetically after construction; e.g. highways. The engineer must bring to the attention of the responsible authorities that needed erosion control measures may significantly increase project cost.

\subsubsection{Retarding Structures (Sedimentation Weirs)}

These are earth embankments, with a principal spillway and an emergency spillway. They may be constructed on or off site, especially in the beds of canyons, gorges or gullies. Their purpose is to store run-off temporarily, releasing it at a slow rate to protect the area below.

They can reduce run-off peaks, permitting the use of smaller culverts etc. as sedimentation weirs in gorges, they collect sediments, hence, letting the gorges fill up slowly. The principal spillway usually consists of a reinforced concrete riser and a horizontal pipe or a monolithic concrete outlet through the earth fill.

A retarding structure should be able to contain run-off expected to occur at a frequency consistent with the level of protection to be provided.

\subsubsection{Diversions}

These are designed, graded channels constructed across a slope. Their purpose is to intercept surface or subsurface water and to lead it to an outlet where it can be safely disposed. The structures may be temporary or permanent; and graded or level. Graded terraces move water in a planned direction at a non-erosion velocity, while level terraces have closed ends and retain the run-off. 
Diversions are useful above cut slopes, borrow areas, and gully-heads, and, also to remove run-off water away from critical construction sites. Diversions should be located such that the run-off water empties into established disposal areas, natural outlets or prepared individual outlets.

\subsubsection{Berms}

Berms are steeps or benches used in steep slopes above $30^{\circ}$, especially in road construction embankments.

- They are modifications of and serve the same purpose as diversions

- Properly located and designed, they reduce slope lengths

- They divide the volume of any run-off into bits

- Run-off may be removed by the use of paved channels or buried pipes

- The risers are prone to erosion, hence, should be protected by vegetation or faced with slope or concrete.

\subsubsection{Wooden Groynes or Wicker-Work Fences}

These are wooden barriers placed across flood channels and act as barriers to sediment transport, especially in slowing down recession flood after a storm has ended. They consist of an assemblage of deadest or quickset segments arranged in discontinuous stretches at a maximum of $5 \mathrm{~m}$ long, staggered and slightly inclined towards the natural depression. Usually, they are constructed of bamboo stakes or other suitable live-stem plants $1 \mathrm{~m}$ long and $4-6 \mathrm{~cm}$ in diameter.

\section{CONCLUSION}

In view of the tremendous capacity for flowing water to dislodge and transport not only soil particles, but, also sand, boulders, trees, other vegetations, and man-made structures in the research area, it is imperative that control measures be devised that will first of all prevent the dislodgement of soil particles and then reduce and maintain run-off velocities at or near levels that will prevent accelerated soil erosion in the area.

There are a number of basic principles for controlling run-off erosion that have proved sound and are well known.

\section{RECOMMENDATIONS}

Following the results of this research, the following recommendations are posited;

- Proper attention should be paid to soil, foundation and topography in site selections

- Minimum exposure of bare areas through the control of clearing and grading operations

- Diversion of run-off water away from critical areas using drains and other erosion control structures should be given prominence.

- Flattening of and/or stabilization of slopes depending on soil type and its angle of repose is very important.

- Slope lengths of erosion control structures are reduced.

- Control of construction equipment access and travel ways

- Use of temporary/permanent vegetative cover is encouraged.

- Organization of public enlightenment programmes is necessary.

- Proper implementation of the remedial measures should be ensured.

- Utilization of soil stabilization measures is of immense benefit.

\section{REFERENCES}

[1] Ajaero, C.K. and Mozie, A.T. (2019). The Agulu-Nanka gully erosion in Nigeria: What does the future hold for the population at risk? In: The Nigerian Field Journal, 44 (3).

[2] Akpokodje, E.G., Olorunfemi, B.N. and Etu-Efeotor, J.O. (1986). Geotechnical Properties of Soils susceptible to Erosion in Southeastern Nigeria. Nig. Journal. App. Sci. 3 (1) Pp. 81-95.

[3] Egboka, B. (1985). The Soil and Water Problems of Anambra State, Nigeria. The Nigerian Geologist, Pp. 86-111. 
Erosion Control in the Erosion-Ravaged Area of Nanka - Adazi-Nnukwu - Agulu Axis of Anambra State, Nigeria

[4] Egboka, Boniface C.E. (1994). Government of Anambra State; The raging War, Erosion and Gullies.

[5] Emmons, W.H. et al. (1960). Geology (principles and processes), $5^{\text {th }}$ edition, John Wiley and sons, New York.

[6] Federal Ministry of Works and Housing (1973). Highway Manual Part 1, Design.

[7] Hudec, P.P.H., Simpson, F., Akpokodje, E.G., and Umenweke, M.O. (2005).

[8] "Anthropogenic Contribution to Gully Initiation and Propagation in S.E. Nigeria, in Ehlen, J., Haneberg, W.C., and Larson, R.A. (Editors). Humans as Geologic agents, Geological Society of America Reviews in Engineering Geology, Xvi, Geological Society of America, Boulder, Colorado, Pp. 149-158.

[9] Morgan, P.R. C. (1978). Soil Erosion and Conservation, Longman Publishers, London.

[10] Nigeria Meteorological Department (2017). Federal Ministry of Transport and Aviation, Abuja, Nigeria.

[11] Nwajide, S.C. and Hoque, M. (1979). Gullying Processes in Southeastern Nigeria. The Nigerian Field Journal, 44 (2), Pp. 64-74.

Citation: Onyeka, J.O., et.al. "Erosion Control in the Erosion-Ravaged Area of Nanka-Adazi-NnukwuAgulu Axis of Anambra State, Nigeria”, International Journal of Constructive Research in Civil Engineering, 5(2), pp. 9-19. DOI: http://dx. doi.org/10.20431/2454-8693.0502002

Copyright: (C) 2019 Authors, This is an open-access article distributed under the terms of the Creative Commons Attribution License, which permits unrestricted use, distribution, and reproduction in any medium, provided the original author and source are credited. 